\section{Crossroads - Early Childhood Education in the Mid-1990s}

\section{LINDA MITCHELL}

\section{Abstract:}

In the 1990s the early childhood community has emphasised the importance of high quality services that provide the best possible environments for young children. Structural features of quality are generally agreed. This paper describes the current provision and quality of early childhood services in New Zealand. It argues that there has been a steady erosion of high-quality publiclyfunded early childhood education and that the competitive free market model is inappropriate for the provision of education services. The paper discusses weaknesses in the state infrastructure that supports early childhood education and inadequacies incurrent funding arrangements. It analyses the $1995 \mathrm{budget}$ decisions with particular focus on free kindergartens. Finally the paper describes an initiative by NZEI Te Riu Roa to develop proposals to take the sector forward on a sound basis into the 21st century.

he Sixth Early Childhood Convention held in Auckland in September 1995 brought exciting discussions of the complexity of young children's thinking and their extraordinary skills and abilities. The power and responsibility of adults to influence children's development was described by Anne Smith (1995) as "awesome". She emphasised how important it is for teachers and other professionals working with children to recognise that adults can "stretch [children's] thinking and have an active role in moving their development forward rather then passively waiting for them to develop on their own" (Smith, 1995, p. 5).

Professionals in early childhood services require supportive conditions, and the government has a key role to play in ensuring these conditions. Early childhood services will offer the best for young children and their families if they are of high quality, provide access to all families with pre-school aged children, and work in partnership with parents and caregivers. Underpinning these features is a requirement for appropriate government funding and a supportive state infrastructure.

\section{Quality and Provision of Early Childhood Education Services}

\section{Features of quality}

High-quality early childhood education has been a recurrent theme since the 1980s. It was the main message at the launch of the "Campaign for quality education in the early years", organised by the New Zealand Educational Institute Te Riu Roa and the Combined Early Childhood Union of Aotearoa in June 1993. Here, Anne Smith's video, "Early childhood educare: the search for quality", showing interviews with respected early childhood educationalists and discussing components of quality, was played to an audience of politicians and educators for the first time.

The briefing to government, "Speaking Directly" February 1994, asked for funding and policies to provide incentives for quality, in order to bring about better outcomes for children, families and society. In addition, three recent reviews (Podmore, 1993; Wylie, 1994; Podmore, 1994) have examined the educational and related outcomes of early childhood education.

Podmore's (1993) review identified characteristics of high quality early childhood programmes as:

- child-centred planned educational programmes

- high staff-child ratios

- trained staff and ongoing in-service training and support

- stability of staff and children

- small group sizes with mixed age groups

- active/democratic parental participation

- language maintenance and cultural revival.

Wylie's (1994) summary of research concluded ( p. 26) that:

What research into early childhood education/care can tell policy-makers is there is solid evidence that it has positive outcomes for children, where it is of adequate quality. The outcomes are diluted or even negative if the quality is poor .... The research in this field can also tell policy-makers that positive outcomes extend beyond individual children and their families to the societies and economies in which they participate. 
Podmore (1994) also warned about the harmful consequences of low quality. Her review paper summarises research findings on the educational and related outcomes of "inadequate" early childhood education and care. She defined "inadequate" as including both the provision of low-quality early childhood centres and insufficient provision for early childhood services generally. Insufficient provision, or lack of access to early childhood services, most strongly affects children "at risk", although all children are adversely affected.

\section{Quality: the current situation}

In 1996, New Zealand has reason to worry about the quality and provision of early childhood education. Since 1990 there has been a steady erosion of high-quality, publicly-funded, community-based early childhood education services. The damaging effects of the 1991 reductions in funding on the quality of childcare have been outlined elsewhere (Mitchell, 1994; Mitchell \& Noonan, 1995). The effects of the 1992 bulk funding provisions on kindergartens are detailed in a later section. Smith et al. (1995) explored the quality of childcare in one hundred childcare centres licensed for under 2-year olds in four main cities in New Zealand. The authors concluded that:

We could be doing better in the overall provision of quality in New Zealand. Our centres do not compare very favourably with the United States centres, except in programme management, learning environment and interacting. This study probably gives a more favourable picture of quality than is the reality since many marginal centres may have declined to participate in the study. (Smith et al, 1995, p. 64)

The comparison with the United States is disturbing. The results of the "Cost, quality and child outcomes study" (Helburn, 1995) by four university research groups in the United States suggest that the quality of care overall is "mediocre", with $40 \%$ of the infant/toddler settings rated as "poor", where health and safety problems are frequent and warm and supportive relationships with adults are not the norm.

The study established that staff wages and their general educational level and specialised training were the factors that discriminated most between centres of high and low quality. More stringent regulations were also linked with higher quality. This finding is replicated by Smith et al. (1995), who found, "Centres which pay their staff an adequate wage, provide them with appropriate working conditions and employ better-educated people, also provide children with a more optimal environment for their development" (p. 64).

Yet in New Zealand there is a shortage of trained and qualified staff, and pay rates and conditions are poor. Only $29 \%$ of staff in childcare services hold the Diploma of Teaching (Early Childhood Education), with an unknown number of other staff holding an equivalence to the diploma.

There are now significant barriers for staff who want to complete or undertake appropriate training: the cost of training; limited availability of appropriate courses; and confusion over standards (Mitchell, 1995). Representatives of the sector have asked for urgent attention to be given to clarifying qualification requirements, removing barriers to accessing training courses, assisting staff who are "in training" and removing the current confusion over licensing points versus qualifications (Quality Funding Working Group, 1995).

Pay rates of staff in the early child hood sector are low. Kindergarten teachers are the lowest paid teachers in the state sector. Childcare workers pay rates vary, but may be as low as the minimum wage. And the rights of workers to fair employment arrangements have been eroded since the passing of the Employment Contracts Act. Indeed the International Labour Organisation's direct contact mission to New Zealand in 1994 found the Employment Contracts Act breached international labour rights associated with collective bargaining. Some of the worst examples of such breaches were provided by NZEI Te Riu Roa of employers in the early childhood sector (NZEI Te Riu Roa, 1994a).

\section{Access to services: the current situation}

The Ministry of Education (1995a) estimates a 30\% increase both in the number of early childhood education providers and in the number of enrolments over the last five years, although between 1993 and 1994 enrolments in playcentre and kohanga reo reduced. It is frustrating that these figures are no more than estimates. Actual participation rates are not known, because children enrolled in more than one centre are counted more than once. Multiple use of services has been described in a National Research Bureau survey (1993), and by Wylie, Kendricks and Meade (1995). The NRB survey suggested that about a quarter of those using some form of education or care used more than one type of service. Wylie et al. (1995) presented information on multiple use of centres, drawn from interviews with 307 parents and caregivers involved in the "competent children" project. They noted (p.7): 
Just under half our sample said that they had used more than one early childhood service at the same time, a phenomenon we call "packaging". Virtually every service other than Kohanga Reo and Pacific Island Language Nest was combined with every other service to produce a wide variety of combinations.

New Zealand needs reliable and detailed statistics on participation rates, as well as on features of parents and caregivers with young children. Inadequate information keeps problems invisible and prevents appropriate planning. The National Advisory Committee on the Employment of Women has developed a proposal for a survey on the demographics, household income and labour market status of parents/caregivers with children under 12 years, their use or non-use of early childhood and after-school care services, and an assessment of employment-related support for workers with family responsibilities. Such data need to be collected regularly, after each census, for example, in order to provide the evidence needed to shape policies that will support caregivers with family responsibilities.

The information currently available on families with young children is that the work of caring for young children is increasingly being carried out in isolation from any immediate family support. Relatives, friends and neighbours may be able to care for children to release the primary caregiver for other activities, but this type of support is not available or adequate for many families. In 1991, just over one-fifth of families looking after a child in its first year of life were sole-parent families, but this rises to a quarter for families in the one-to-four age group (Statistics New Zealand, 1994). Within Maori and Pacific Islands ethnic groups, the proportion of sole parents is higher.

The high cost of childcare services has become prohibitive, even if families are eligible for, and use, the Department of Social Welfare childcare. AGB:McNair's (1994) study of fees in childcare centres showed many centres charge $\$ 120$ to $\$ 139$ per week, with some fees going as high as $\$ 180$ per week. Provision of services is haphazard. The Ministry of Education has taken a "hands off" approach to planning of new services and co-ordination of existing services. There is no requirement to provide evidence of community planning before newly established centres can become licensed and receive government funding.

In the childcare sector, commercial for-profit centres now outnumber community-based centres by 640 to 409 . Evidence is mounting that for-profit centres provide lower-quality care and education (Smith et al., 1995; Clifford, 1995). There should be no contest between what is best for children and the desire of entrepreneurs to make a profit. Yet in New Zealand, the growth of for-profit centres has been allowed to surge without check. There are no requirements for these services to involve parents, caregivers and staff in decisionmaking, and there is lesser financial accountability to the government than in the community-based sector. There have been obvious cases of misuse of government funding, where money intended for education has been spent on private assets (Parent Advocacy Council, 1991; CECUA, 1990; Education Review Office, 1991). The most recent example brought to light was the Wallace House Childcare Centre, which in 1994 was shown to have paid $\$ 18,000$ of government funding to the Bread of Life Bakery and donated a further $\$ 20,000$ to church groups, while workers were unpaid and the centre went bankrupt! (NZEI Te Riu Roa, 1994b).

Wylie et al. (1995) found that location was the dominant reason for parents/caregivers' choice of early childhood service. Other factors were the needs of the parent (for example to take part in paid employment), parental perception of reputation or standards, sibling attendance, opportunities for parental involvement, programme, type of service, cost and facilities. The findings tally with evidence on voucher education in the United States that, given a "choice" of schools, it is not educational quality that parents pursue - the main factors are geography and location. Evidence in the early childhood sector shows that even if educational quality were the main factor in determining parental choice of service, parents may not have the knowledge and understanding to choose the type of centre which offers quality (Barraclough, 1995; McDonald, 1993).

All pre-school children and their families in New Zealand should have access to an early childhood service that is of high quality and meets their needs, because only then are there benefits. This aim can be met by careful community planning, appropriate funding levels and arrangements and a supportive state infrastructure. The view that the market will ensure the establishment of suitable services and that parental choice can be relied on for quality assurance is not borne out by the available evidence.

\section{The State Infrastructure}

More stringent regulations and higher standards for early childhood education services, appropriate monitoring of those standards, and a sound support and advisory service make a difference to quality. Clifford's (1995) paper showed that, in the United States, external influences of standards and regulations can act to raise quality. Meade 
(1993) argued that the state infrastructure is one of the key factors. If the state infrastructure loses its coherence, even when good investments are made elsewhere in staff and centre environments, we do not have quality and we have no benefits.

In New Zealand, poor co-ordination between relevant government agencies and policy inconsistencies currently characterise their operation. This frustrates the development of quality (Mitchell, 1995). Smith et al. (1995) note that the current mechanisms of licensing and monitoring do not seem to be working to maintain quality standards. The Education Review Office (ERO) is constrained by the number of audits it is practically able to undertake, by the nature of the audit, and by the standards against which it reviews (legislative requirements, regulations, contractual obligations, and statement of desirable objectives and practices). Only 331 out of 3,752 centres received assurance audits in 1995, and there were 35 discretionary audits. It should be noted that these are not effectiveness audits, simply assurance audits, assessing the activities of the centres against stated criteria.

The ERO's 1995 education evaluation report was highly critical of the present early childhood regulatory arrangements, and questioned whether those arrangements were sufficient to ensure each child is well cared for and actively educated on a fully professional basis. It has recommended that policy regulations be introduced to allow more monitoring of structural and process quality (Hurst, 1995).

Within these restrictions, the ERO is able to report on noncompliance with requirements and make recommendations. It is then the responsibility of the Ministry of Education (or other regulatory authorities) to take action on its report. But there seems to be an unwillingness on the part of the Ministry of Education to take strong action on non-complying centres. Hurst (1995) noted evident frustration both from centres and the ERO regarding the existence of noncomplying centres.

One of the most distressing accounts of non-compliance is described in the Education Review Office (1994) Assurance Audit Report on the Gabby Goose Childcare Centre (a for-profit centre). It indicated noncompliance with the centre's licence and charter, "in all aspects of the centre's operation including curriculum management and implementation; aspects of health, safety and welfare; physical environment; record keeping; general management and administration, and personnel management". Some of the many examples cited were:

- no evidence to show that programmes had been planned, implemented or in any way reviewed to meet the requirements of the curriculum section of the charter or to meet the developmental needs of children. "For example, during the review a crying child was put into a cot by the licensee and left to cry for 35 minutes without any further consideration by staff" (p. 3).

- $\quad$ record keeping did not meet requirements. "For some children regularly attending the centre there are no records other than having a note of the child's name .... different dates of birth for the same child appear on different documents" (p. 5).

- records of accidents, illnesses and medication administered at the centre were incomplete.

- an audited financial statement was not available for the last financial year.

- the licence was not current. Attendance of enrolled children had on several occasions exceeded the maximum number stated on the licence.

- staff employed did not have any relevant early childhood qualifications (apart from the centre owner who was also the "person responsible").

- many practices in the centre were "unsafe and unhygienic". For example, "the staff changed children in the play area beside the kitchen and they were not sighted cleaning their hands after this. One staff member observed to not clean her hands was responsible for making morning tea and lunch" (p. 8).

- facilities in use were "inadequate, unsafe, cold, unhygienic and do not meet even minimal standards as required for childcare centres" (p. 10).

The Ministry of Education has the power to suspend or cancel any licence or withdraw the charter. But, "In practice, ... [these] sanctions are rarely exercised - and only when the welfare of children is sufficiently jeopardised" (Smith, Lockwood, 1994b, p. 5). The review listed 60 actions required to meet compliance, and recommended that the Ministry of Education review the licence. In this case, the Ministry did not see fit to cancel it. Instead, it granted a provisional licence with 15 conditions. The ERO discretionary audit on 14 February 1995 concluded that a high level of non-compliance still existed, with compliance having been achieved in only 30 of the actions. 


\section{Funding Levels and Delivery}

Evidence presented to the Quality Funding Working Group, set up to determine criteria for the new funding levels announced in the 1995 Budget, heard that financial difficulties are threatening quality and viability of centres across the sector. Levels of funding are inadequate. By international comparisons, New Zealand is underspending on early childhood education (OECD, 1993). The funding formula is insensitive to the needs of different services and particular communities. For example, the importance of early childhood services in the passing on of language and culture is a role that is crucial for Maori and for small ethnic communities. Yet the funding formula provides no special recognition of the needs of Maori in either mainstream services or in nga kohanga reo. Nor does it cater appropriately for Pacific Islands immersion education. Difficulties are especially evident in rural and low socio-economic communities which struggle to cope in the wake of the widespread social problems caused by economic restructuring.

The Department of Social Welfare childcare subsidy, intended to provide fee relief for low income families, has inherent problems. These are the inability to control expenditure, expensive and time-consuming administrative procedures, inability to link funding with quality, and exclusion of families who are at the margins for subsidy eligibility. Families using the subsidy enter in to a "poverty trap" and are in danger of being stigmatised.

\section{Early Childhood Education Policies: the 1995 Budget and the}

\section{Government's Response to the Employment Task Force}

The 1995 budget decisions were to increase spending in early childhood education as follows:

- \$34 million for early childhood services over three years;

- $\$ 13$ million to increase participation in parents as first teachers from 3,000 families to 9,000 families;

- 10 million on more special education assistance in early childhood education.

The changes to funding early childhood services were:

- $\$ 5$ per hour for under twos and $\$ 2.50$ per hour for children two and over to all chartered early childhood services meeting certain "quality" requirements. (The existing rates of $\$ 4.50$ and $\$ 2.25$ per hour would continue for chartered services not reaching the "quality" requirements);
- for kindergartens not moving to the new rates, an increased hourly rate of $\$ 2.90$ (from $\$ 2.875$ ) but with the existing restriction of 24 hours per week and 320 sessions per year;

- the Department of Social Welfare childcare subsidy available to all early childhood services charging fees and funded at $\$ 2.25 / \$ 4.50$ or $\$ 2.50 / \$ 5.00$.

Key changes were also announced to charter and regulatory requirements (Ministry of Education, 1995b):

- the development of specific quality standards and self-evaluation procedures for inclusion in the Desirable Objectives and Practices;

- the development of a comprehensive range of sanctions for noncompliance with regulations and charter requirements;

- the addition of a review power for the Education Review Office to review licence-exempt services.

The Government's 19 October 1995 report Focus onEmployment outlined further spending and policy changes:

- $\quad$ early childhood centres to be funded for up to six hours per child per day regardless of the times the child is in the centre, with a maximum of 30 hours a week, a change from a funding basis of two three-hour sessions per day (\$23.3 million over three years);

- the government to take over the funding of Anau Ako Pasifika (\$400,000 per annum);

- funding to assist Pacific Islands early childhood centres to become licensed (\$3 million over three years).

In three critical respects the 1995 government policy decisions were a welcome departure from previous approaches.

First, the linking of funding with quality indicators of staff-child ratios and staff qualifications showed the government's willingness to fine-tune its funding policy to encourage higher quality. Its previous approach to allow the market to decide, within a framework of minimum regulation, provided no incentive for centres to improve their quality. It is significant, too, that the criteria for staff training was to be set at a "qualification" rather than at "licensing points". "Licensing points" do not necessarily include core components or achieve the high standard of training available through the Diploma of Teaching (Early Childhood Education). The intended changes to charter and regulatory requirements go some way to addressing important issues regarding the Education Review Office powers. 
Secondly, the decision to consult the sector over the details of the new funding criteria and on changes to charter and regulatory requirements, was a far cry from the approach taken in the two reviews of early childhood funding which had been carried out in 1991 and 1993 by officials behind closed doors. The funding review group had recommended (Smith, Lockwood, 1994a, p. 9), "On balance, the Ministry of Education supports limited consultation between the Minister of Education and key early childhood groups to determine the likely behavioural responses of the sector to the proposals." It had warned (p. 9) that "consultation could result in advocacy of particular solutions that do not necessarily conform to the government's overall fiscal priorities."

In fact, the Quality Funding Working Group set up to advise on the new funding criteria faced difficulties because of a short time frame, limited ability to meet together, and insufficient information about trained staff. Significantly, the Working Group agreed on important recommendations that fell outside the terms of reference. These asked for the base level of funding to services to be raised and additional funding to assist unlicensed centres to become licensed. There were recommendations for a working group representing the sector to develop a comprehensive long-term funding policy for early childhood education, with a focus on equity, quality and service-specific issues, and for a study of the difficulties facing the sector over qualifications and training issues. The independent chairperson refused to put these agreed recommendations into the final report! However, his decision was overturned at a meeting on 30 August 1995 between the working group and Hon John Luxton.

Thirdly, early childhood education is starting to be viewed in a wider context. The childcare needs of families in paid employment supplement the aims expressed in Education for the 21st Century for parent education, the education of young children under school age, and their preparation for school. Wylie, Hendricks and Meade (1995) show the use parents make of their time while their child is at an early childhood education centre: in paid work, participation in the early childhood service itself, housework, farmwork, looking after children, the mother's own interests, visiting friends and relatives and voluntary work. But these wider roles are not recognised in current policy, which is described by officials as

... involving two complementary strategies. One involves parent support which assists parents to participate more effectively in their children's development, and is provided to parents in the home setting. The other involves early childhood services in the provision of care and learning opportunities to young children predominantly in group situations and support for their families. (Smith, Lockwood 1994a, p. 2)

The statement reflects the current policy direction, which treats the Parents as First Teachers programme as the main means of providing parent education, and overlooks the enormous contribution offered by centre-based services to parent education and support.

There is a shift to fully fund services for the parent in the home and a move to strengthen the Social Welfare funding model for centre-based services. The Parents as First Teachers programme was expanded in 1994 and 1995 and is fully funded to cover all the costs of co-ordinators' salaries, operating costs and professional development costs. For centrebased services, full costs are not met and their funding arrangements highlight the government's preoccupation with "user-pays" and a "welfare net" for those categorised as needy. The government's attempts to privatise free kindergartens illustrate its views that state funding of centre-based early childhood services should be on a user-pays basis, with a minimum subsidy.

\section{State involvement in free kindergartens}

Kindergartens are the flagship for publicly-funded, community-based, high-quality early childhood services. The early childhood sector supported the "Before Five" policies which aimed to provide equitable funding for all early childhood services, with improved levels of kindergarten funding to enable better staff:child ratios. The aim was to make all early childhood services equally accessible and of good quality. But the present government not only shelved the "Before Five" staged funding plan, it sought to remove the responsibility of the state for free kindergartens, and reduce kindergarten funding to the lower level of other early childhood services. The government laid the ground by reducing the state's responsi-bility for kindergartens as follows:

- removing the legal impediment to kindergartens charging fees (Finance Bill, No.2, 1990) and so opening the path to user pays;

- making registration of teachers voluntary (December 1990) and thus allowing untrained teachers to be employed;

- introducing bulk funding of kindergartens (1 March 1992) so that the government no longer had direct responsibility for paying teachers' salaries. Bulk funding rates were based on 1991 expenditure; 
- through the State Sector Amendment Act s.74, 1989, enabling the State Services Commission to delegate its responsibility for negotiating conditions of employment.

Only an agenda of privatisation can easily explain why the government in its 1995 Budget should virtually "freeze" kindergarten funding, by giving an increase of less than one percent (the only increase to kindergarten hourly rates since bulk funding was introduced).

The Education and Science Select Committee during October and November 1995 heard evidence from NZEI Te Riu Roa, NZ Free Kindergarten Associations and Kindergarten Federation associations on the position of free kindergartens. The hearing was a response to over 16,000 signatures on 263 petitions organised by NZEI Te Riu Roa calling for an increase in kindergarten funding. There were more petitions on this issue than had been received on any other issue. NZEI Te Riu Roa (1995) described cost increases since 1992 with respect to deferred maintenance, current operations and new buildings. Kindergartens have needed to comply with new regulations, improve staff-child ratios and pay for a $2 \%$ salary increase negotiated by the State Services Commission.

Kindergarten associations have made ends meet by reducing teachers' employment conditions, pushing up group sizes (because more children attract more funding), and in some instances, disbanding senior teachers and special needs positions. Maintenance in many associations has been deferred. There is now evidence of an erosion of quality, severe teacher recruitment and retention problems, increased stress and workload for staff and volunteers, and threats to access in rural communities and areas of special educational need. This evidence is summarised in NZEI Te Riu Roa (1995).

The goals of equitable funding under the "Before Five" provisions have been replaced by arguments for equal funding at the level of the lowest common denominator. So, the Ministry of Education (1995c) writes:

The kindergarten sector appears to be advocating for a return to the former funding system where some services received preferential funding treatment from government. Under current policies the government buys educational hours of a particular quality from early childhood services and overall is neutral in terms of service type.

The Associate Minister of Education, the Hon John Luxton, reiterates the arguments, "For many years, kindergartens have been paid substantially more an hour than any other early childhood education provider, often for a similar service" (Waikato Times, November 11, 1995). There is pressure for kindergartens to charge fees."... if [kindergartens] choose to move to the new rate, they may charge a fee and parents can then access the DSW subsidy. Other providers, such as Te Kohanga Reo, already charge fees." (Waikato Times, November 11, 1995) His comments reflect a desire to lessen state responsibility. "It was also doubtful that kindergartens were part of the state sector," Mr Luxton said during a rare appearance by a minister at a select committee" (Williams, 1995). In fact, free kindergartens are part of the state sector and are included in both the State Sector and Education Acts.

The campaign by NZEI Te Riu Roa, the Wellington Region Free Kindergarten Association and NZ Free Kindergarten Associations to resist privatisation and secure increases to kindergarten funding is vitally important, not only for free kindergartens themselves but for the future direction of the whole sector. It is some achievement that the Education and Science Select Committee on 20th February 1996 recommended to the government that it give favourable consideration to an increase in kindergarten funding. The 1996 budget will indeed need to announce funding improvements if kindergartens are to face a healthy future.

\section{The Early Childhood Education Project: Future Directions}

It is against this background that NZEI Te Riu Roa resolved to work in partnership with other early childhood organisations on a major project on the future directions of early childhood education. It was felt that, in order to move beyond short-term, ad hoc decision-making, with policy driven by a "New Right" ideology, the early childhood sector as a whole needed to regain control and come up with sound proposals to share with the public.

The project aims to analyse the key issues confronting early childhood education and provide a model for future policy directions. Representatives from major early childhood organisations: Te Kohanga Reo Trust, NZ Childcare Association, Pacific Islands Early Childhood Council of Aotearoa, NZ Playcentre Federation, NZ Family Day Care Association and NZ Free Kindergarten Associations have come together with NZEI Te Riu Roa to form the project group. The broader early childhood constituency is being kept informed and invited to participate. The encouragement and maintenance of quality is the main reference point for the group. The project aims to pinpoint the policies, relationships, structures and funding arrangements that promote quality 
education. The group has received information from its consultation networks to review existing arrangements and issues for the early childhood sector, including consideration of the extent to which the work of government agencies and legislation support quality and access.

The project has commissioned Coopers \& Lybrand economist, Suzanne Snively, to analyse the costs of early childhood education. The analysis will estimate the value of volunteer services, donated goods, government funding, parent fees, donations and money raised through fund-raising efforts. The analysis of costs will then provide a database against which the group can compare costings of its funding proposal.

The group intends to launch a draft report and distribute it for wide consultation at the end of March 1996. The final report will be published before the national elections, expected towards the end of 1996.

It is necessary to establish a culture within the early childhood sector where sector groups work in partnership with the government to develop sound long-term policy. This early childhood project will help to establish that culture. The development of a supportive state model where quality early childhood services are provided as a partnership between families/whanau, local communities and government representing the interests of society as a whole is in the long term most effective.

\section{References}

AGB:McNair. (1994). Survey of fees charged by childcare centres. Prepared for Ministry of Education, Wellington.

Barraclough, S. (1995). Parent choice and childcare quality - a New Zealand study. Paper presented to New Zealand Association for Research in Education Conference, Christchurch, New Zealand.

Clifford, R. M. (1995, September). Cost, quality and child outcomes in childcare centers in the United States. Address to the Sixth Early Childhood Convention, Auckland, New Zealand.

Combined Early Childhood Union of Aotearoa. (1990). Discussion paper on bulk funding. Prepared for the Ministry of Education, Wellington.

Education Review Office. (1991). National special review. Use of funding by childcare centres. Wellington.

Education Review Office. (1994, August 8). Confirmed assurance audit report: Gabby Goose Childcare Centre. Wellington: ERO.

Education Review Office. (1995). Early Childhood Learning Programmes. Wellington: ERO.
Government of New Zealand. (1995, October 19). Focus on employment. The Government's response to the Employment Task Force and the MultiParty Group Memorandum of Understanding. Wellington.

Helburn, S. W. (Ed.) (1995). Cost, quality and child outcomes in childcare centres. Technical Report, University of Colorado.

Houghton, R. M. \& Wilson, A. G. (1993). The introduction of bulk funding, including salaries of kindergartens: Etablishment of 1992 baseline for monitoring. Dunedin: University of Otago Consulting Group.

Hurst, K. A. (1995). Monitoring quality in early childhood education. Final research report to Ministry of Education, Wellington.

McDonald, H. (1993, February). Early childhood and work/family issues in North America. Report of a research placement to Ministry of Women's Affairs, Wellington.

Meade, A. (1993, June). Start with quality. Speech at the launch of the Campaign for Quality Education in the Early Years, Wellington.

Ministry of Education. (1994a). Education for the 21stcentury. Wellington: Learning Media Ltd. for the Ministry of Education.

Ministry of Education. (1994b). Speaking directly! Briefing to governmenton early childhood education. Ministry of Education.

Ministry of Education. (1995a). Growth in early childhood education. Education Trends Reports, 7 (1).

Ministry of Education. (1995b, May). Early childhood education policy changes. Information for management and staff of early childhood services. Wellington.

Ministry of Education. (1995c). Report on kindergarten funding issues, including Whitiora Kindergarten. Report to Education and Science Select Committee, Wellington.

Mitchell, L. (1994). What has happened to early childhood education? Women's Studies Journal, 10 (2), 97-102.

Mitchell, L., and Noonan, R. (1994, October). Early childhood education. Paper presented to the International Year of the Family Symposium on the rights and responsibilities of the family. Wellington, New Zealand.

Mitchell, L. M. (1995, September). Early childhood education: future directions. Paper presented to the Sixth Early Childhood Convention, Auckland, New Zealand.

National Research Bureau. (1993). Survey of caregivers of children under five - use of ECE services. Auckland.

NZEI Te Riu Roa. (1994a). Evidence against the Employment Contracts Act. Submission to the International Labour Organisation Direct Contact Mission, Wellington, New Zealand. 
NZEI Te Riu Roa, (1994b). Childcare centre closure reveals shock findings. Rourou, 5 (4), 1.

NZEI Te Riu Roa, (1995). Submission to the Education and Science Select Committee. Funding for Kindergartens.

Organisation for Economic Co-operation \& Development, (1993). Economic surveys, New Zealand. Paris: OECD.

Parent Advocacy Council, (1991). Annual report for the year ended 30 June 1991. Wellington

Podmore, V. N. (1993). Education and care: a review of international studies of the outcomes of early childhood experiences. Wellington: New Zealand Council for Educational Research.

Podmore, V. N. (1994). Early childhood education and care: a summary review of the outcomes of inadequate provision. Wellington: New Zealand Council for Educational Research.

Quality Funding Working Group, (1995). Criteria for eligibility for quality funding. Report to the Associate Minister of Education.

Renwick, M. \& McCauley, L. (1995). Group size in kindergartens: issues arising from changes to group size and other policy developments in the Wellington Region Free Kindergarten Association in 1994. New Zealand Council for Educational Research, Wellington.

Smith, A. B. assisted by Ford, V. E., Hubbard, P. M. \& White, E. J. (1995). Working in infant childcare centres. Final research report to Ministry of Education. Dunedin: University of Otago.

Smith, Anne B. (1995, September). Keynote address to the Sixth Early Childhood Convention, Auckland, New Zealand.

Smith, Lockwood (1994a, December 1). ECE1: Review of early childhood funding - overview. Office of the Minister of Education.

Smith, Lockwood (1994b, December 1). ECE3: Review of early childhood funding - regulatory framework. Office of the Minister of Education.

Statistics New Zealand (1994). New Zealand now: Families. Wellington, New Zealand.

Williams, M. (1995, November 29). Luxton rejects kindergarten funding complaints. The Dominion.

Wilson, A. G. \& Houghton, R. M. (1995). The introduction of bulk funding, including salaries of kindergartens: financial and operational impact for 1993 and 1994. Dunedin: University of Otago Consulting Group.

Wylie, C. (1992). First impressions: The initial impact of salary bulk funding on New Zealand kindergartens. Wellington: New Zealand Council for Educational Research.
Wylie, C. (1993). The impact of salary bulk funding on New Zealand kindergartens: Results of the second national survey. Wellington: New Zealand Council for Educational Research.

Wylie, C. (1994). What research on early childhood care/education can and can't tell policymakers? Wellington: New Zealand Council for Educational Research.

Wylie, C., Hendricks, A.K., and Meade, A. (1994, DECEMBER ??). Early childhood education services: what works for parents? Paper presented to NZARE Conference, Christchurch, New Zealand.

\section{The author}

Linda Mitchell is a Senior Research Officer with NZEI TE Riu Roa. 